\title{
The Impact of Technology on North Indian Agricultural Practices
}

\author{
Rajinder S Jutla* \\ Department of Geography and Urban Planning, Missouri State University, USA
}

Submission: February 06, 2017; Published: March 09, 2017

"Corresponding author: Rajinder S Jutla, Department of Geography and Urban Planning, Missouri State University, Springfield, MO 65804, USA, Email: RajinderJutla@MissouriState.edu

\section{Opinion}

When India gained independence from British colonial rule in 1947, the agricultural practices were based on primitive technologies employing oxen and plough and for rain, farmers depended on the seasonal monsoon. The agricultural output per hectare was low and there was tremendous poverty in rural areas. I remember this growing up in the northern part of India and visiting our ancestral village in Punjab in early 1960s as a young boy. In 1960 there was a food shortage as result of droughts for two to three consecutive years. As a result India had to import wheat mainly from Australia and the United States.

To address the serious issue of food shortage, pioneering agricultural methods to increase productivity were introduced in India in the early 1960s. These methods were first launched in the north Indian states of Punjab, Haryana and Uttar Pradesh. The use of a variety of high yielding seeds and the increased use of fertilizers along with good irrigation is known collectively as the Green Revolution. This was based on new seed-fertilizer technologies which developed in the 1960s for tropical developing countries. As a way to increase wheat yields, semidwarf wheat was developed and experimented in Mexico by Dr. Norman Borlaug, American plant pathologist and Nobel Peace Prize winner. This variety accounts for more than ninety percent global wheat acreage and was found to be quite suitable for the North Indian region.

The aim of the Green Revolution was to increase food production to make India self-sufficient in food grain. The plan was implemented only in areas with assured supplies of water, large inputs of chemical fertilizers, and availability of adequate farming loans. To assure a large quantity of water for irrigation, ground water was exploited by individual farmers who constructed their own tube wells. In a relatively short time, agricultural production increased manifold. This dramatic increase in the quantity was reflected in the size of vegetables which became very large and therefore could feed more people. I remember seeing: for example, Daikon radish that was previously 10-12 inches long with a diameter of 1-2 inches becomes over two feet long with a diameter of 4-6 inches after the Green Revolution. Northern India and in particular Punjab, was termed the "breadbasket" of the entire country and placed India on the way to becoming self-sufficient in food production. However this was mainly confined to wheat crop.

Farmers were also able to grow more than one crop within a year and this raised their income level. The ability to grow more food also helped to feed the growing Indian population. It also meant less land was now needed to grow more food per hectare. The transition from primitive agricultural practice to modern green revolution also required more capital to buy expensive chemical fertilizers and high variety yield seeds. This was partly addressed by state governmental subsidies and loans. To cut down intensive labor and also meet labor shortage farmers needed agricultural machinery for their farm efficiency.

In early 1960's, there was a scarcity of agricultural machinery, such as tractors. This demand was met by import. Farmers were encouraged to import tractors without excise duty. In 1950, there were 8,000 tractors in use and by 1960 , this number reached 39,000 [1]. Nowadays, India has overtaken the United States as the world's largest producer of four-wheel tractors.

The change in agricultural practices slowly created regional disparities and economic imbalances. In a very short time, farmers who had relatively large farms became prosperous and to keep their high productivity, they invested large amounts of money. Many of them bought tractors and ownership of a tractor even became a status symbol in rural areas. This was not economically feasible for farmers with small parcels of land but still they invested in tractors thus incurring debt. Agriculture for small and marginal farmers became more difficult since the cost of running farms gradually increased and in recent times have become tremendously high. 
Not only did the cost of fertilizers, pesticides, and gasoline increase sharply, but tube wells became expensive. For the last five to six decades, the Green Revolution has consumed a fairly large amount of ground water leading to a drop in the water table level in many areas. This has led to tremendous costs in the installation of tube wells since deep drilling has to be done in order to get water from the ground. It is not economically feasible for a small farmer to make such investments since the interest rate on loans is extremely high (18 to 36 per cent). Production levels in North Indian states and particularly Punjab have already touched the saturation point and productivity cannot be increased further by intensive use of inputs [2].

Also, with the growing population land holdings have become divided among family members. Many farmers have either small parcels of land of their own or they lease it from other farmers. Obtaining credit from banks or agricultural cooperatives to sustain their farms has become virtually impossible. Those farmers who are already under debt or with bad credit turn to money lenders who charge exorbitant interest rates. The farmers ultimately are forced to turn over their produce to the money lenders in order to pay off their debt. This vicious cycle of incurring debt to continue with cultivation with the hope of turning their finances around to repay old loans also with high interest pushes farmers to the brink of despair, severe depression and ultimately suicide.

Mann [3] in The Tribune reports that 166,304 farmers committed suicide in India from 1997-2006, and the number of farmers have declined by 9 million from 2001 to 2011. This is the first absolute decline of the agrarian population since 1971.
Ironically, this is the population that had formed the backbone of the Indian economy. The farming community is at an increased risk of disappearing and so agriculture issues should be addressed. There is a need to diversify the existing paddy-wheat crop pattern and venture into different avenues such as dairy and poultry farming as well as fruits, vegetables and flowers.

Technology has certainly increased food production in Northern India in the last sixty years. However in recent times it has led to undue pressure on the land and the small farmers. Costs are high and less workers are needed to operate farms. This has resulted in severe unemployment in rural areas where there is no other alternative employment sector. For small farmers who have enjoyed a prosperous past and relatively higher standard of living during the peak of the Green Revolution, life has become uncertain and catastrophic. They were the pioneers who initiated agricultural progress and helped put the country on the path to self-sufficiency in food production. In order to continue along this path, the Central and State governments should develop agricultural policies based on sustainability: maintaining a healthy environment while balancing social equity with economic profitability.

\section{References}

1. Singh G (2015) Agricultural Mechanization Development in India. Indian Journal of Agricultural Economics 70(1): 1-31.

2. Kaur P (2015) Why Punjab farmers are driven to suicide. The Tribune Online Edition.

3. Mann SK (2015) Soften the harsh realities of farming. The Tribune Online Edition.

Your next submission with Juniper Publishers will reach you the below assets

- Quality Editorial service

- Swift Peer Review

- Reprints availability

- E-prints Service

- Manuscript Podcast for convenient understanding

- Global attainment for your research

- Manuscript accessibility in different formats

( Pdf, E-pub, Full Text, Audio)

- Unceasing customer service

Track the below URL for one-step submission https://juniperpublishers.com/online-submission.php 